\title{
Sex of Previous Children and Desirability of the Next Child: A Follow-up Study of Unwanted Children
}

\author{
ANTERO MYHRMAN \\ Laboratory Supervisor \\ Department of Public Health Science \\ University of Oulu
}

\section{Introduction}

Studies dealing with the having of an additional child after two or more children have shown the sex composition of the previous children to have a slight but significant effect (Carr-Hill et al., 1982; Cutright et al., 1974, Gray and Morrison, 1974; Goody et al., 1981; Freedman et al., 1960; Thomas, 1951), and it has also been found that reaching the ideal family size is a more effective factor in limiting family size than is the sex composition of the family (Gray and Morrison, 1974; Cutright et al. 1974; Thomas 1951). Although there has been some change in sex preferences from a preference for boys towards a balanced sex preference, the trend is still in favor of boys (Dunnell, 1979; Riihinen et al., 1980). Thus Carr-Hill et al. (1982) found that families from the lower social classes tended to have an additional child if they had only girls.

The study on unwanted children born in northern Finland included less families with children of one sex than the control groups of wanted children (Rantakallio and Myhrman, 1980). The aim of the present paper is therefore to determine how constant this pattern of behavior is. Do families continue to have an additional child more often if there are children of one sex in the family than if there are both sexes? There is hardly any literature describing families who continue to have children because of sex preferences and the effects of this aspect on the children are almost unexplored (see Williamson, 1976). The main purpose of this study is to compare the families with children of one sex who wanted an additional child with matched families who did not want the child and to assess the possible effects on the child.

\section{Material and methods}

The series originated from a survey of 12068 pregnant mothers in the two northernmost provinces of Finland, Oulu and Lapland. The investigation was started at the sixth or seventh month of pregnancy and covered $96 \%$ of all deliveries in the region in 1966 . The desirability of the pregnancy was ascertained by proposing the alternatives: "The mother finds that this pregnancy a) occurred at a propitious time, b) would have been more desirable later, c) should not have occurred at all». $12 \%$ of the mothers said that the pregnancy was unwanted, and $63 \%$ that it was desired (Rantakallio, 1969).

The follow-up study on the children born from these unwanted pregnancies concerned the stage at which the children had completed their first year at school. 300 children, about one fifth of the total, were chosen for study by systematic sampling. Each child was assigned a control from among the children born from desired preg- 
nancies, chosen so that the families would be similar at the time of birth in respect of social group and the marital status and parity of the mother. Questionnaires were sent separately to the family and the teacher of the child. 284 of the families with an unwanted child and 283 of the controls (95\%) answered the questionnaire, the corresponding figures for the teachers being $271(90 \%)$ and $274(92 \%)$.

The study group consisted of families with from two to four children of the same sex born before the unwanted or wanted child, the number of such families with an unwanted child being 20 and that with a wanted child 39 . The control group contained families with children of both sexes. The number of families is 110 with an unwanted child and 89 with a wanted child.

\section{Results}

\section{Sex composition}

The families who did not want the additional child differed in sex composition from those who wanted the child. There were significantly less families with children of one sex in the unwanted group than in the wanted group, the difference being pronounced among the families with three children (Table 1).

$\mathrm{T} \mathrm{a} \mathrm{b} \mathrm{l} \mathrm{e} \mathrm{1.} \mathrm{Desirability} \mathrm{of} \mathrm{the} \mathrm{child} \mathrm{in} \mathrm{families} \mathrm{of} \mathrm{different} \mathrm{sex} \mathrm{composition.}$

$\begin{array}{cccc}\text { B }=\text { boy } & \text { Third child } & \begin{array}{c}\text { Families with } \\ \text { unwanted child }\end{array} & \begin{array}{c}\text { Families with } \\ \text { wanted child }\end{array} \\ \mathrm{G}=\text { girl } & \text { B B (B) } & \text { N } & \text { N } \\ & \text { B B (G) } & 2 & 5 \\ & \text { G G (B) } & 3 & 4 \\ & \text { G G (G) } & 3 & 5 \\ \text { both sexes } & 3 & 6 \\ & 20 & 21\end{array}$

$\chi^{2}=1.149$, df 1 , ns

Fourth child
B B B (B)
B B B (G)
G G G (B)
G G G (G)
both sexes

children of one sex/both sexes:

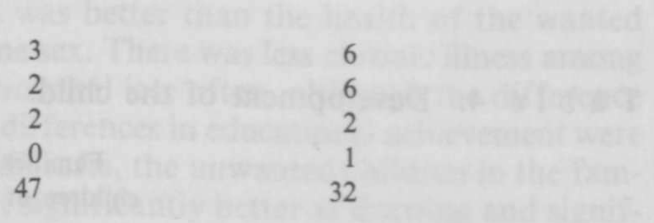
$\chi^{2}=4.285$, df $1, \mathrm{p} \leqq 0.05$

Fifth child

B B B B (B)
B B B B (G)
G G G G (B)
G G G G (G)
both sexes

children of one sex/both sexes: $\chi^{2}=0.940$, df 1 , ns

After eight years' follow-up the difference still existed between the families with an unwanted and a wanted child, being pronounced now among those with three and four children. Further examination of those families who continued to have an additional child after the child in question showed that the sex composition of the family had no effect on the having of an additional child in the group with wanted children whereas there was a tendency among the families with an unwanted child having only boys to continue to have another child more often (Table 2, p. 56). 
$\mathrm{T}$ a b 1 e 2 . Families with $3-5$ children who continue to have another child after the unwanted/wanted child by sex composition.

\begin{tabular}{|c|c|c|c|c|c|}
\hline \multirow{3}{*}{$3-5$ children } & \multicolumn{3}{|c|}{$\begin{array}{l}\text { Families with } \\
\text { unwanted child }\end{array}$} & \multicolumn{2}{|c|}{$\begin{array}{l}\text { Families with } \\
\text { wanted child }\end{array}$} \\
\hline & $\mathrm{N}$ & & & $\mathrm{N}$ & \\
\hline & & $\mathrm{N}$ & $\%$ & & $\mathrm{~N}$ \\
\hline B $\ldots$ (B) & 5 & 4 & 80 & 12 & 4 \\
\hline B ... (G) & 6 & 1 & 17 & 10 & 3 \\
\hline G . . (B) & 5 & 1 & 20 & 7 & 2 \\
\hline G . . (G) & 4 & 0 & 0 & 10 & 3 \\
\hline both sexes & 110 & 28 & 25 & 85 & 27 \\
\hline
\end{tabular}

T a b l e 3. Family characteristics.

\begin{tabular}{|c|c|c|c|c|}
\hline \multirow{2}{*}{ 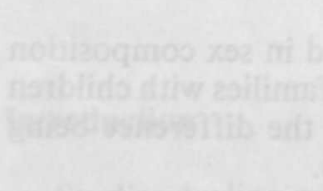 } & \multicolumn{2}{|c|}{$\begin{array}{l}\text { Families with } \\
\text { children of one sex }\end{array}$} & \multicolumn{2}{|c|}{$\begin{array}{l}\text { Families with } \\
\text { children of both sexes }\end{array}$} \\
\hline & $\begin{array}{l}\text { Unwanted } \\
\text { child } \\
\text { N } 20\end{array}$ & $\begin{array}{l}\text { Wanted } \\
\text { child } \\
\text { N } 39\end{array}$ & $\begin{array}{l}\text { Unwanted } \\
\text { child } \\
\text { N } 108\end{array}$ & $\begin{array}{c}\text { Wanted } \\
\text { child } \\
\text { N } 88\end{array}$ \\
\hline Appliances & $\%$ & $\%$ & $\%$ & $\%$ \\
\hline television & 95 & 97 & 91 & 86 \\
\hline washing machine & 70 & $97^{*}$ & 89 & 94 \\
\hline car & 55 & 64 & 69 & 70 \\
\hline \multicolumn{5}{|l|}{$\begin{array}{l}\text { Care of the child } \\
\text { child prepares own }\end{array}$} \\
\hline $\begin{array}{l}\text { breakfast } \\
\text { no adult at home }\end{array}$ & 20 & 26 & 19 & $10^{\circ}$ \\
\hline after school-hours & 25 & 11 & 21 & $9^{*}$ \\
\hline \multicolumn{5}{|l|}{ Child's possessions } \\
\hline bicycle & 65 & $92^{* *}$ & 70 & 76 \\
\hline skis & 85 & 95 & 90 & 95 \\
\hline skates & 56 & 63 & 64 & 66 \\
\hline
\end{tabular}

$\mathrm{T} \mathrm{a} \mathrm{b} 1$ e 4. Development of the child.

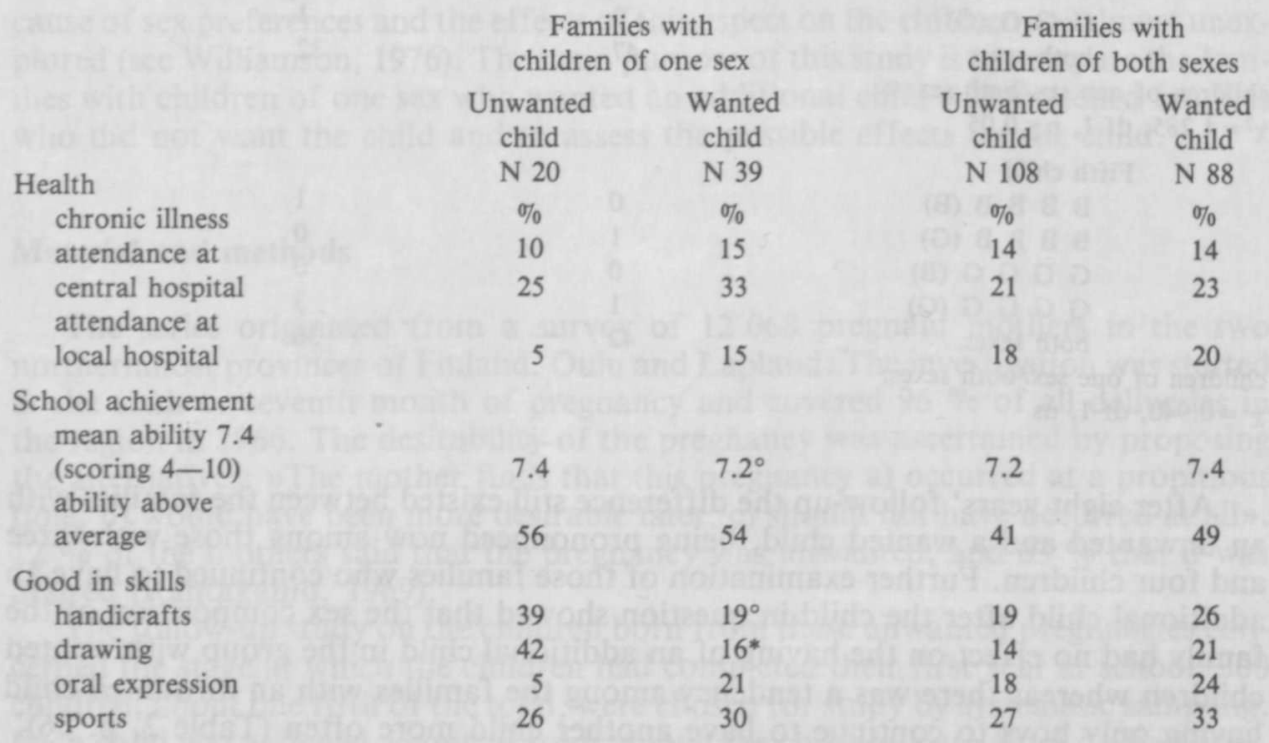




\section{Social change}

The families had been selected so that the social group and marital status were the same in the families with unwanted children and with wanted children. There were some differences, however, in the subgroups of families with children of one sex, in that the social status was higher among the families with an unwanted child at the time when this child was born but the situation was reversed eight years later. There had been more upward mobility in the group with a wanted child ( $21 \%)$ than in that with an unwanted child $(15 \%)$, whereas downward mobility had been more common in the families with unwanted children (15\% compared with $5 \%$ ).

Total change in social status was $40 \%$ in the group with unwanted children and $36 \%$ in the group with wanted children, farmers included. There were also some changes in marital status, $95 \%$ of the mothers with unwanted children and $92 \%$ of those with wanted children being married at the birth of the child, whereas eight years later the corresponding figures were $85 \%$ in the group with unwanted children and $90 \%$ in the group with wanted children.

\section{Family}

As far as the question of whether the families with children of one sex showed any special characteristics with respect to the desirability of an additional child was concerned, the families with children of one sex who wanted an additional child were found to be better off than those who did not want to have the child. They had certain household appliances more often than the families with an unwanted child, the difference being statistically significant in the case of owning a washing machine, and the same was also true of the children's possessions, e.g. a bicycle. The care of the unwanted children was usually more problematic than for the wanted children, the difference being significant before school-hours and almost significant after schoolhours, but the problem of taking care of the children was not so pronounced in the families with children of one sex (Table 3).

\section{The child}

The health of the unwanted children was better than the health of the wanted children in the families with children of one sex. There was less chronic illness among the unwanted children and they were in hospital less often, although the difference was not statistically significant. Statistical differences in educational achievement were obtained in the cases of drawing and handicrafts, the unwanted children in the families with children of one sex being almost significantly better at drawing and significantly better at handicrafts than the wanted children in the families with children of one sex (Table 4).

The adjustment of the children to school differed between the families with children of one sex and with the children of both sexes, the wanted children in the latter group having better relations with their teachers than the unwanted children. They were almost significantly more open towards their teachers, and significantly more often found it easy to cooperate with them. The opposite was true in the families with children of one sex, where the unwanted children were more open towards their teachers and also cooperated more easily, although there was no statistical difference between the unwanted and wanted children because of the low number of cases (Figure 1, p. 58).

\section{Discussion}

The gender effect among the children was found here after parity three, as in a study concerning large families, whereas in smaller families the gender preference 
F i g u r e 1. Attitudes towards the teachers among families with children of one sex
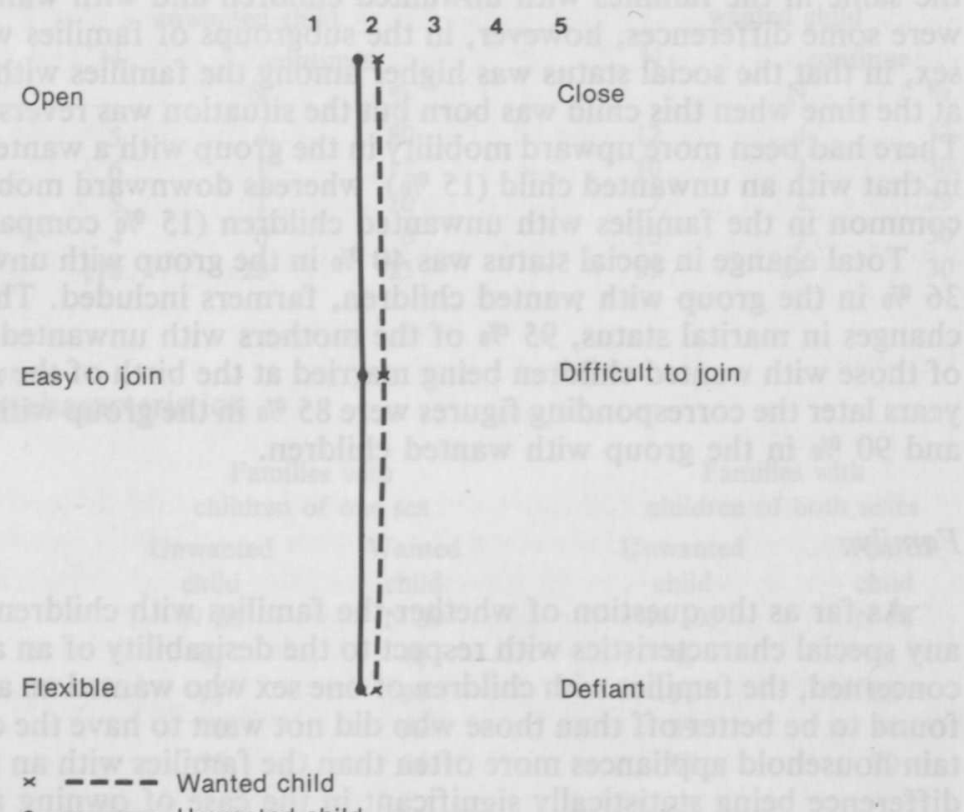

- Unwanted child

was found to be concentrated at parity two (Gray and Morrison, 1974). Gender preference has a small, limited effect on the number of children as a function of changes in the level of intended numbers of children. This result has been confirmed by Cutright et al. (1974) and Sloane and Lee (1983).

One surprising result was that school adjustment educational achievement were poorer in the families with children of one sex where the child examined was wanted than in those where this child was unwanted, the statistical differences being almost significant or significative. These differences are not due to the social status of the families, since this was poorer among the families with an unwanted child. Previous studies on unwanted children have shown that social and educational development is poorer in these than in their controls (Matějšcek et al., 1978). One possible explanation is that sex preference is not necessarily a good motive for having a child.

\section{References}

Carr-Hill, R.; Samphier, M.; and Sauve, B. (1982). Socio-demographic variations in the sex composition and preferences of Aberdeen families. Journal of Biosocial Science 14: 429-443.

Cutright, P.; Belt, S.; and Scanzoni, J. (1974). Gender preferences, sex predetermination, and family size in the United States. Social Biology 21: 242-248.

Dunnell, K. (1979). Family Formation, 1976. Office of Population Censuses and Surveys, HM Stationery Office, London.

Freedman, D.; Freedman, R.; and Whelpton, K. (1960). Size of family and preference for children of each sex. American Journal of Sociology 66: 141-146.

Goody, J. R.; Duly, C. J.; Beeson, I.; and Harrison, G. (1981) Implicit sex preferences: a comparative study. Journal of Biosocial Science 13: 455-466.

Gray, E.; and Morrison, N. M. (1974). Influence of combinations of sex of children on family size. The Journal of Heredity 65: 169-174. 
Matějšcek, Z.; Dytrych, Z.; and Schüller, V. (1980). Follow-up study of children born from unwanted pregnancies. International Journal of Behaviour Development 3: 243-251.

Myhrman, Antero (1982). Undesired pregnancy and children's life circumstances. Yearbook of Population Research in Finland XX: 68-87.

Rantakallio, Paula (1969). Groups at risk in low birth weight infants and perinatal mortality. Acta Paediatric Scandinavia Suppl. 193.

Rantakallio, P. and Myhrman, A. (1980). The child and family eight years after undesired conception. Scandinavian Journal of Social Medicine 8: 81-87.

Riihinen, O.; Pulkkinen, A.; and Ritamies, M. (1980). Suomalaisen perheen lapsiluku. Väestöntutkimuslaitoksen julkaisusarja D (Publications of the Population Research Institute, Series D), No. 7,

Sloane, D. M.; and Lee, Che-Fu. (1983). Sex of previous children and intentions for further births in the United States, 1965-1976. Demography 20: 353-367.

Thomas, M. H. (1951). Sex patterns and size of family. British Medical Journal 1: 733-734.

Williamson, N. E. (1976). Sons or daughters? A cross-cultural survey of parental preferences. Sage Publications, Beverly Hills, Ca. 